\title{
Explaining Private Debt
}

\author{
LENNO UUSKÜLA \\ Bank of Estonia *
}

\begin{abstract}
The paper examines the relationship between more than 30 macroeconomic variables and debt-to-GDP ratios for the household, non-financial corporation and aggregate debt in a panel of European Union countries. The GDP level and the ratio of house prices to income are found to be positively correlated with the debt-to-GDP ratio, whereas the real interest rate, the inflation rate, economic sentiment and the government debt level are negatively correlated with the debt-to-GDP ratio. Low interest rates and the house priceto-income ratio predict growth in the future debt-to-GDP ratio. Moreover, countries that have had a financial crisis have typically gone through a period of deleveraging afterwards.
\end{abstract}

Keywords: private debt, macroeconomic conditions, correlation, forecasting

JEL Classifications: E44, E3

\section{Introduction}

The level and dynamics of private borrowing from the financial sector have been an increasing concern for economic policy since the global financial crisis. Policy makers often refer to excessive credit levels, such as when the Governor of Sveriges Riskbank Stefan Ingves expressed concerns about debt dynamics in an interview with Dagens Nyheter (Ingves 2014). Very high levels of debt are considered to hamper growth (see for example Cecchetti et al. 2011) because of debt overhang (Eggertsson and Krugman 2012) and the possibility of debt deflation (Fisher, 1933). In addition to the problems of excessive debt levels, levels of debt being too low might be a sign of weakness in the financial sector (Svirydzenka 2016) or poor financing conditions for households and firms.

\footnotetext{
* Research Division, Economics and Research Department, Bank of Estonia. Email: lenno.uuskyla@eestipank.ee, Address: Estonia pst 13, Tallinn 15095, Estonia, Phone +(372) 6680880. The views expressed are those of the author and do not necessarily represent the official views of Eesti Pank or the Eurosystem. I would like to thank the Editor, anonymous referees, seminar participants at the Bank of Estonia, and Robin Hazlehurst, Jana Kask, Olavi Miller, Martti Randveer, Taavi Raudsaar, Tairi Rõõm and Karsten Staehr for their valuable comments, and Olavi Miller and Evelin Viilmann for their help in getting the data.

(C) 2016 Lenno Uusküla. Licensed under the Creative Commons Attribution - Noncommercial 3.0 Licence (http://creativecommons.org/licenses/by-nc/3.0/. Available at http: //rofea.org.
} 
Several macroprudential measures have been introduced recently to avoid sudden hikes that would make the debt of the private and financial sectors reach levels that are considered to be excessive, in order to protect the financial sector from adverse effects that might arise from the non-financial private sector. It is equally vital for government policies to pay attention to the dynamics of private debt, as in times of recession, government might have to take banks over in difficulties, in which case private debt becomes public debt and can result in fiscal sustainability problems (Borio et al. 2016).

This policy paper studies the factors that are correlated with household debt, non-financial corporate sector debt, and aggregate private debt ${ }^{1}$ across countries and time. It not only looks at debt levels, but it also assesses whether these factors can help to forecast future changes in debt. The division into household and non-financial corporate sectors creates a richer dataset than simple aggregate private debt, making it possible to ascertain differences between household and corporate behaviour. By using economic theory, the paper proposes several groups of macroeconomic variables that should be related to debt levels and changes in debt. The paper focuses on the relationships in a panel of European Union countries because the financial sector is especially relevant for European countries as European firms rely on banks and debt instruments much more than those in the US do.

Aggregate private debt level is zero in a standard simple representative agent closed economy model because agents are all identical and the interest rate adjusts. In a closed economy it is the heterogeneity among economic agents, such as patient and impatient or rich and poor households, or young and old agents, that shifts the equilibrium debt level above zero. In open economies, differences in interest rates, the business cycle stages, patience or the demographics of countries are sufficient to generate steady state debt levels that are different to zero. Hence there are many variables that should be related to the level and change of debt, and this paper weighs more than 30 of them in understanding private debt.

The approach of the paper is exploratory and regression models are kept simple in order to provide a first-hand overview of the dynamics and correlations across macroeconomic variables. I study the relationships in European Union countries from 1970 for Western Europe and from the 1990s for the countries in Central and Eastern Europe at quarterly frequency. The panel regression analysis is divided into two. First I study the contemporaneous correlation of the variables with the level of debt at quarterly frequency. Second, I study the changes in the level of debt, predicting a five-year change in the debt given current economic conditions. The paper does not go beyond correlations, though the timing of the equation of the changes might mean that a causal interpretation is possible in some cases.

\footnotetext{
${ }^{1}$ I use the words credit, debt and indebtedness interchangeably to refer to the debt-to-GDP ratio. As a shorter version of non-financial corporate debt, I also refer to the debt of firms, as only one type of debt is used in the model.
} 


\section{UUSKÜLA Explaining Private Debt}

The paper finds that real GDP per capita is strongly correlated with all three debt measures. The richer countries are, the higher their debt levels are. Higher house price-toincome ratios are positively related to the level of debt, and low interest rates are also related to higher debt levels. It also finds that the higher the government debt and inflation rates are, the lower the aggregate indebtedness of a country is. Countries experiencing a financial crisis have higher debt levels on average than those with no crisis. Some of the variables that have contemporaneous correlations can also forecast future developments in debt. Low interest rates lead to increasing levels of debt, whereas a financial crisis means on average that the country facing it is going through a deleveraging process. Equally countries with high house price-to-income ratios tend to witness a decreasing debt levels further down the line.

The paper contributes to the growing empirical literature understanding debt and savings behaviour. There are a number of studies that look at the relationship between financial markets and macroeconomic variables in individual countries. For the USA, Albuquerque et al. (2014) find that house prices, interest rates, unemployment, and home ownership are important in the long-run debt relationship, like in this paper, but their study is limited to the relationship with debt on a very limited set of variables and considers only the US. Borio (2014) analyses financial cycles and looks at the relationship with GDP cycles in the USA. The results confirm the findings of this paper on interest rates, as he finds some suggestive evidence that interest rates can be related to developments in the financial sector.

Tudela and Young (2005) and Waldron and Zampolli (2010) look at the dynamics of debt in the UK and relate developments to house prices, housing ownership, interest rates, inflation, credit constraints and demographics in theoretical setups. Unlike all those papers, the current paper considers a wide range of countries and many possible macroeconomic variables, providing more general results than single country studies that might be driven by idiosyncratic domestic factors. A lot of attention has been paid to government debt, even more so in relation to the European sovereign debt crisis that struck after the great recession of 2008 (Ostry 2015). Equally this paper is related to the analysis of debt intolerance by Reinhart et al. (2003) and many others. This paper finds that government debt is related negatively to private debt levels.

Kukk and Staehr (2015) estimate a model for the household and corporate savings rates, running the regression on several macroeconomic variables on a panel of Central and Eastern European countries. In contrast to their focus on savings, this paper looks instead at debt dynamics. Randveer et al. (2011) observe that countries with a higher debt level have slower recoveries than those that have lower indebtedness, and Kask et al. (2005) analyse the effect of debt on the length and severity of a crisis, but neither of them looks at the variables that are correlated with debt. The paper by Cihak et al. (2012) focuses on how financial development affects the real economy, but it does not consider the relationship from the economy to the financial sector. 
Using microdata, Mian and Sufi (2011) show that higher house prices lead to higher borrowing in the USA. Thwaites (2015) builds a theoretical model that can help explain an increasing level of indebtedness for young households and house prices with a fall in the relative price of investment goods. This paper studies these relationships empirically for a group of European Union countries.

The paper starts with a short presentation of the econometric approach in Section 2 and continues with a discussion of the data in Section 3. Section 4 presents the main results in two parts. The first shows the results for the level regression and then continues with the model explaining future developments. Section 5 presents results for additional analysis and, finally, Section 6 concludes.

\section{Econometric models}

I use panel data to study debt in levels and study the forecasting properties of selected variables. These level and forecasting models capture different aspects of the data and are complementary in analysis. The regression approach does not allow causality from the explanatory variables to the debt-to-GDP ratio to be evaluated, but it gives an idea how they evolve together over time.

First, I estimate the model on contemporaneous levels using quarterly data. This captures the correlation of the macroeconomic variables with indebtedness. The regression on the debtto-GDP ratio is:

$$
y_{i, t}=a+b t+c x_{i, t}+e_{i, t}
$$

where $y_{t}$ is the debt level-to-GDP ratio of country $i$ at period $t$. The vector $x_{i, t}$ contains explanatory variables, the vector $c$ contains the estimated coefficients, $a$ is a constant term, $t$ stands for the trend, $b$ is the coefficient of the trend, and $e_{i, t}$ is the residual term.

This approach seeking to establish contemporaneous correlation of the variables in levels allows the maximum length of the available data to be used and it allows models to be estimated using variables where only short time-series are available. The model setup is similar to Kukk and Staehr (2015), Chowdhury (2004) and many others for national savings, but does not have the lagged value of the dependent variable as an explanatory variable. I have chosen not to include the lagged debt-to-GDP ratio in the models, so the parameter estimates for the level regression still have the interpretation on the level of debt and not on changes to it.

Theoretically, the debt-to-GDP ratio should be stationary. It can include structural breaks, but it cannot grow or shrink unboundedly. However, the debt level is increasing in the sample, so simple stationarity tests indicate that some of the series can have a unit root in a univariate setting. Unit root tests allowing for structural breaks can reject the unit root of the 


\section{UUSKÜLA Explaining Private Debt}

debt-to-GDP ratio in several cases where the simple test did not reject the unit root, but the unit root cannot be rejected for all countries. As it is hard to test structural breaks close to the beginning and end of the sample and because the sample finishes right after the financial and sovereign debt crisis in Europe, then I also run the stationarity tests on a restricted sample finishing at the end of the boom. This improves the test results for stationarity even further. I include a linear trend in all regressions and decide on the statistical significance using standard tests and then also run the model on changes in the debt-to-GDP ratios.

The benchmark model for the changes predicts debt dynamics five years ahead given current economic conditions. This gives an indication of whether the current values of economic variables are able to predict the dynamics of debt. The regression is:

$$
y_{i, t}-y_{i, t-20}=a+c x_{i, t-20}+e_{i, t}
$$

where the dependent variable $y$ is the change in the debt-to-GDP ratio $y$ of country $i$ during a period of five years. Five years is enough to smooth out most of the business cycle developments as it is around the average length of business cycles that are between 1.5 and 8 years in length. Shortening the period would give more emphasis to the business cycle relationship, whereas making the period longer would reduce the sample size even further. The setup is similar to that in Cecchetti et al. (2011), where the dependent variable is the average economic growth rate in a five-year period, which is explained by the five-year averages of the independent variables. This exercise is carried out as a robustness analysis. The current setup of regressing the future change in debt on the contemporaneous values of the macroeconomic variables gives higher degrees of freedom.

As the level regression might pick up short-run cycles, I use an approach that is less sensitive to high frequency dynamics and business cycles. I add to the evidence for the level equation at quarterly levels by calculating the five-year moving average of indebtedness and regress it on the same five-year moving average period of the explanatory variables. The regression equation is:

$$
y_{i,(t, t-19)}=a+b t+c x_{i,(t, t-19)}+e_{i, t}
$$

where the debt-to-GDP ratio is $y_{i,(t, t-19)}$ for country $i$ during the average of a five-year (20quarter) period between time $t$ and $t-19$. A very similar approach with moving averages is also used by Cecchetti et al. (2011). The weakness of the approach compared to the quarterly level equation (1) is that it requires a longer time series and there are insufficient data available for several variables.

The future movement in indebtedness might also depend not only on the current economic conditions, which might be volatile at quarterly frequency, but also on how the economy has evolved over a longer horizon. For additional evidence to the model on changes in 
indebtedness five years ahead, I also estimate a model where the explanatory variables are five-year averages, which is similar to the regression of the debt level:

$$
y_{i, t}-y_{i, t-20}=a+c x_{i,(t-20, t-39)}+e_{i, t}
$$

where the time period $(t-20, t-39)$ refers to the moving average of the variable during the fiveyear period preceding the change in the debt level of the left hand side variable.

All the models are estimated fixed effects. The fixed effects model uses within country variation, and in this respect the paper follows the approach by Islam (1995) and Cecchetti et al. (2011). For additional analysis, the models are also estimated using random effects, which give economically very similar results. Standard errors are clustered by countries for all regressions. I do not use GMM as the number of countries is smaller than the number of time periods.

\section{Data}

This section explains the choice of potential variables. The candidate factors that influence the level of debt are divided into seven somewhat overlapping categories: (1.) global, (2.) financial, (3.) national economy, (4.) households and real estate, (5.) demographics, (6.) government, and (7.) institutions. I will discuss each of them briefly and give a summary of the possible factors and variables together with their expected effects. An overview of the data with the notation, selected descriptive statistics and data sources is presented in Table A1 in the Appendix.

The global financial conditions (1.) determine international financial flows. Among many financial variables, the level of the interest rate is a measure for the availability of financing. For the overall cost of financing I include the nominal (Nominal interest rate) and the real (Real interest rate) three-month money market interest rates, where consumer price inflation has been used to calculate real interest rates from nominal rates. I use the ex post real interest rate, using actual inflation and not expected inflation to make the series real. The sign of the relation can be either positive or negative. When the substitution effect prevails, then low interest rates should lead to higher indebtedness as it is cheaper to borrow and substitute future consumption with consumption today. When the income effect prevails then low interest rates make people feel poorer and lead to a drop in the level of debt. The correct variable to use from a theoretical point of view is the real interest rate, for example Thwaites (2015) stresses the importance of low real interest rates in borrowing. But as there are several potential deflators for the nominal interest rate, and it is not a priori clear what gives the real rate that is correct for both households and firms, I also include the nominal interest rate as this gives a good description of the nominal costs of saving and borrowing decisions. Borio (2014) suggests that interest rates and global monetary policy gaps may be related to financial 


\section{UUSKÜLA Explaining Private Debt}

developments. King and Low (2014) propose using a world real interest rate for international monetary conditions, but national money market interest rates express the international liquidity position together with the national factors that should describe better the overall liquidity stance for a country. I include the current account balance (CA balance) as a measure of global financial flows. Jeanne (2010) and Broto et al. (2011) both stress the importance of volatile capital flows in emerging markets, as open economies have little control over international capital flows. The current account can also be taken as a measure of national liquidity and inflows of resources. Obstfeld (2011) stresses the role of international liquidity and Cesa-Bianchi et al. (2015) identify the effect of global liquidity shocks on house prices in a variety of developed and emerging economies.

For the domestic financial sector (2.) I discuss several variables that are related to domestic financial institutions and credit availability. I use different measures of bank capitalisation (Capital reserves), capital reserves to total assets (Capital reserves to assets), change in bank assets (Bank assets), and the leverage ratio (Leverage ratio). The better capitalised the banks are, the easier it should be for them to access external financing, and this should result in a higher level of indebtedness. However, having a lot of capital might also mean that the banks are not giving out many loans and are well capitalised for that reason. Cihak et al. (2012) gives a good overview of different financial development indicators and their relationship to private debt. For loan conditions I use the access to finance index (Access to fin.), which measures the availability of credit for the corporate sector, though whether it is correlated with household debt could also be tested. Better access to finance should be related to higher debt. A similar measure is the variable for bank lending survey credit standards (BLScs). Loan spread (Spread) is another measure for financial sector efficiency, risk and the willingness to give loans (Waldron and Zampolli 2010). Low spreads, like interest rates, might be either positively or negatively related to debt as high rates might lead people to take fewer and smaller loans or to make the period for paying back loans longer. I also look at the debt level and dynamics dependent on all the financial crisis indicators (Financial crisis) as dummy variables taken from the paper by Detken et al (2014), measuring the state of health of the financial sector.

The national economy (3.) is represented in the regressions by a set of real and nominal variables. I include the log of a level of real GDP per capita (Real GDP p.c.), while GDP level is a measure of economic development that is potentially correlated with the development of the financial system, though it might also have the opposite causal interpretation as a strong financial system can help an economy to achieve high levels of GDP. For the relationship between the level of GDP and debt, see Shaw (1973) and Svirydzenka (2016) for a recent overview. As the left hand side variable is a ratio of nominal debt to the level of nominal GDP, then higher GDP lowers the debt level for a given level of nominal debt, but this effect is expected to be smaller than the relations between the financial sector and economic 
development. The current GDP growth rate measured in logs (Real GDP growth) captures the growth potential of the countries. High growth might be related to increasing debt when growth is taken as a sign of future development or is due to increased borrowing activity. Growth is, however, negatively related to debt when debt is used for consumption smoothing as debt is paid back in good times and households and firms borrow in periods of low economic activity. I also control for episodes where the debt level can increase because of a drop in GDP (Recession), and this is a variable that has values different from zero only when the GDP growth rate is negative. I also discuss the correlation with the unemployment rate (Unemployment) for the US, which was shown to be important by Albuquerque et al (2014), and the economic sentiment index (Economic sentiment) of the European Commission to measure trust in the economic conditions as higher confidence should lead to lower saving and higher borrowing.

Continuing with the variables that are related to the domestic economy, I use a set of variables related to inflation. The domestic consumer price index (CPI) inflation rate (Inflation) is used to calculate the real interest rate, but change in the current CPI can play a role on its own. High inflation can lower the level of debt in the current period. Alternatively a higher inflation rate can lead to higher expected debt by increasing the incentive to take loans as consumption now becomes relatively cheap compared to consumption in the future. As quarterly inflation might be volatile in some countries and periods, I include the average inflation rate over the previous year (CPI mean). In addition, stable low inflation can measure the stability and predictability of the economy. The lower the inflation rate is, the more stable the economy is and the higher indebtedness is. In addition to the level of inflation, its volatility (CPI vol.) in the last five years can be a good measure of the stability of the expected nominal revenue generated to pay back a loan. In this case higher volatility should lead to a drop in the debt level.

For describing households and real estate (4.), the variable for the rate of home ownership (HOall) captures the need to finance housing with a loan and the share of households with a mortgage (HOwm) and those without one (HOnm). In a theoretical model Vogel (2014) relates the equilibrium level of government debt to inequality and more generally to differences across households. Moreover, real estate prices should be strongly correlated with indebtedness as suggested by Waldron and Zampolli (2010) and the study by Jordà et al. (2016). Real estate affordability, which is the ratio of house prices to income (House prices to income), also describes the willingness of households to take loans to finance mortgages. In addition, I use the real estate price index (RE price) and commercial real estate prices (Comm. RE price) as in Albuquerque et al. (2014), and real equity prices (Equity prices). Mian and Sufi (2011) find evidence that a dollar increase in the value of housing collateral leads to 25 to 30 cents of additional borrowing that is used for consumption or house improvement. I also include a house affordability index which demonstrates how expensive it is for households to 


\section{UUSKÜLA Explaining Private Debt}

finance buying a flat or a house out of labour income. The higher prices are, relative to wages, the higher household indebtedness should be, as the household has to borrow more and take a longer time to pay back the loan.

Theory suggests that several demographic (5.) factors are important for borrowing activity. A large younger generation relative to the older generation should increase the amount of loans as young households borrow against their future income and the old use their savings. A lower share of dependent people in the total population (Dependency rat.) could potentially be correlated with higher indebtedness as there are more potential loan clients. Even though the population size is stable or decreasing in many countries, households are becoming smaller, resulting in the number of households in Europe rising. Smaller household size (HHsize) requires more separate housing and it is therefore more likely that a higher share of households will have mortgages.

For the government sector (6.) I study the role of the government budget balance and government debt. High government debt (Govt. debt-to-GDP ratio) means a high tax burden for given levels of government expenditures and transfers. Higher expected taxes result in lower expectations of future income and therefore also lower debt levels. In addition a high level of government debt might reflect the level of government intervention, the availability of public housing and so forth. Obstfeld (2011) stresses the role of national governments in managing international liquidity. Budget balance (Govt. budget balance) is a measure of the change in the government debt and shows the future sustainability of government finances. Higher deficits give an indication of the current budget stance and should lead to a higher level of public debt and lower private debt as people expect more taxes. The sign might be reversed when government spending induces, or is expected to induce, an economic boom and offers economic stability, in which case economic confidence might increase to the extent that people take on more debt because the economic prospects are good.

Finally, the loans of companies depend on various specific institutional issues (7.). I use two measures in this paper. Firstly, the availability of external finance for firms from the stock market can be captured by stock market capitalisation (SMC). The more difficult it is to start a business (time to start a business (TSB)), the fewer firms are created and the less firms can afford in loans. There are a number of additional factors that are likely to be correlated with the indebtedness variable, but the inclusion of additional data is left for future research.

The panel consists of the following European countries with data availability for the quarters listed: Austria 1995Q4 - 2012Q4; Belgium 1980Q4 - 2012Q4 for household debt and up to 2012Q3 for non-financial corporate debt; Czech Republic 1995Q4 - 2012Q4; Croatia 1996Q4 - 2012Q4; Cyprus 2004Q1 - 2012Q3; Denmark 1970Q4 - 2012Q4; Estonia 2003Q4 - 2012Q4; Finland 1970Q4 - 2012Q4; France 1977Q4 - 2012Q4; Germany 1970Q4 - 2012Q4; Greece 2000Q4 - 2011Q1; Hungary 1995Q4 - 2012Q4; Ireland 2002Q1 2012Q4; Italy 1970Q4 - 2012Q4; Latvia 1997Q2 - 2012Q4; Lithuania 1995Q4 - 2012Q4; 
Review of Economic Analysis 8 (2016) 153-176

Malta 2003Q4 - 2012Q4; Poland 1995Q4 - 2012Q4; Portugal 1979Q4 - 2012Q4; Romania 200Q4 - 2012Q4; Slovakia 2003Q4 - 2012Q4; Slovenia 1995Q4 - 2012Q4; Spain 1980Q4 2012Q4; Sweden 1980Q4 - 2012Q4; the Netherlands 1982Q4 - 2012Q2 for household debt and up to 2012Q1 for non-financial corporate debt; the UK 1970Q4 - 2012Q4 for household debt and from 1976Q1 onwards for non-financial corporate debt. Data for Luxembourg are excluded from the regression analysis because the country is a financial centre and Bulgaria is not included because of data availability issues. For total non-financial sector private debt, I use the sum of the household and non-financial corporate debt.

The country coverage is not full for some of the explanatory variables, so models with different explanatory variables are used for different country groups. Not all the variables have the same coverage over time, and some, such as demographic factors are available only for very short time periods. Including all the variables at the same time is therefore not a feasible strategy. Instead I start by estimating bivariate regressions of the level equation (1), using one explanatory variable at a time in addition to a constant and a time trend. The results are presented in Table A2 in the Appendix. The coefficients estimated have the meaning of conditional correlation given the fixed effects and the time trend. From the individual parameter estimates I select those that are statistically significant at conventional levels and for which at least a total of 1500 observations are available, and I continue with the more standard approach of general to specific estimation (see for example Campos et al., 2005). I drop one-by-one the variables with the lowest t-values in the regression, taking account of possible multicollinearity issues arising from the data. I keep the variables included in the three regressions the same so as to give better comparability and ensure the same samples are used in the three regressions of the three debt variables. Starting from all the variables would restrict the sample by explaining only a subset of the data and hence generality would be lost.

\section{Main results}

The regression results depict conditional correlations with several macroeconomic variables, controlling for other variables. I start from the debt level regressions at quarterly frequency and continue with the forecasting exercise in the next subsection.

\subsection{Debt level regressions}

The first column of Table 1 demonstrates the conditional correlation coefficients for household debt, the second column presents the results for non-financial corporate debt, and the third column shows the regression results for total debt. All the models are estimated using Equation (1). As a measure of global financial conditions, the money market interest rate is negatively correlated with all three debt variables, and the relationship is statistically significant at least at the $95 \%$ confidence level for the non-financial and total debt measures. 


\section{UUSKÜLA Explaining Private Debt}

Table 1: Debt level regression results for households, non-financial corporations and total debt at quarterly frequency.

\begin{tabular}{|l|c|c|c|}
\hline & Households & Non-fin. corp. & Total \\
\hline \hline Real interest rate & -0.126 & $-0.725^{* *}$ & $-0.850^{* *}$ \\
& $(0.228)$ & $(0.286)$ & $(0.344)$ \\
Financial crisis & $10.123^{* * *}$ & $10.186^{* *}$ & $20.231^{* * *}$ \\
& $(2.865)$ & $(3.848)$ & $(5.864)$ \\
Real GDP p.c. & $0.498^{* * *}$ & $0.777^{* * *}$ & $1.274^{* * *}$ \\
Unemployment & $(0.138)$ & $(0.155)$ & $(0.152)$ \\
& 0.825 & $3.184^{* * *}$ & $4.016^{* * *}$ \\
CPI mean & $(0.567)$ & $(0.724)$ & $(0.500)$ \\
& -1.485 & $-10.725^{* * *}$ & $-12.215^{* *}$ \\
Economic sentiment & $(3.178)$ & $(2.891)$ & $(5.514)$ \\
& $-0.203 * * *$ & $-0.358^{* * *}$ & $-0.561 * * *$ \\
House prices to income & $(0.067)$ & $(0.073)$ & $(0.128)$ \\
& $0.255^{* * *}$ & 0.224 & $0.479 * * *$ \\
Govt. debt-to-GDP ratio & $(0.083)$ & $(0.131)$ & $(0.114)$ \\
& 0.045 & $-0.464 *$ & $-0.420^{* *}$ \\
& $(0.151)$ & $(0.244)$ & $(0.181)$ \\
\hline Observations & 1195 & 1193 & 1193 \\
R-squared & 0.675 & 0.672 & 0.779 \\
Number of countries & 21 & 21 & 21 \\
\hline
\end{tabular}

Notes: Robust standard errors in parentheses, ${ }^{* * *} \mathrm{p}<0.01,{ }^{* *} \mathrm{p}<0.05,{ }^{*} \mathrm{p}<0.1$.

A real interest rate one percentage point ( $\mathrm{pp}$ ) higher is related to a $0.9 \mathrm{pp}$ lower debt-to-GDP ratio. It shows that the substitution effect is stronger than the income effect. Interestingly the correlation is not significant for the household, which might be a sign that the income effect is stronger. The results confirm previous findings in the theoretical papers of Waldron and Zampolli (2014) and Tudela and Young (2005), and empirical literature, such as the importance of the real interest rate in Albuquerque et al. (2014), King and Low (2014) and Borio (2014).

Unemployment and GDP per capita, as measures of the domestic economic conditions, are positively correlated with the level of debt. A 1pp higher GDP level is related to a $0.5 \mathrm{pp}$ higher debt-to-GDP ratio for households and $0.8 \mathrm{pp}$ higher debt-to-GDP ratio for firms. This is a key variable in understanding the debt levels across countries and their dynamics over time. The GDP level for longer periods for many countries looks very similar to a linear trend. In these regressions however, the trend became statistically insignificant and was therefore 
dropped. Hence, in this sample financial deepening is not picked up by a common trend that would explain global financial trends, but is explained by country level developments. Unemployment and consumer price inflation are more strongly related to non-financial and total debt than to household debt. The finding confirms the relationship that Borio (2014) documents between the financial and GDP cycles. Unemployment is a cyclical measure that could pick up the increased borrowing of firms in times of recession. In contrast, Albuquerque et al. (2015) find a negative relationship between debt and unemployment for the US. High inflation helps to lower the indebtedness of firms or means uncertainty about the future that would also end in a reduction of indebtedness, and the importance of this is consistent with the theoretical papers of Tudela and Young (2005) and Waldron and Zampolli (2010).

The very weak relationship between unemployment and debt suggests that although households may like to borrow more at times when they face low income, they borrow during low income periods only to a limited extent. The negative sign of the economic sentiment index (Economic sentiment) goes along with the sign of unemployment, as the lower confidence is, the more households and firms borrow, this being consistent with the consumption smoothing hypothesis.

Another economically important correlation is the positive relationship between the house price-to-income ratio and indebtedness for households and firms. A 1pp. increase in the house price-to-income ratio is related to a $0.3 \mathrm{pp}$ higher debt level. The more expensive houses are, the more households need to borrow for longer horizons. This confirms the theoretical consideration that house prices are important in the papers by Tudela and Young (2005) and Waldron and Zampolli (2010). House prices have also been found to be a significant driver of the debt in Waldron and Zampolli (2010), Albuquerque (2014) and Mian and Sufi (2011) for various countries and periods.

Government debt seems to matter more for firms than for households. Firms behave according to the Ricardian hypothesis that high government debt means more taxes and hence smaller available income in the future. Smaller income in the future results in lower levels of debt. A 1pp. higher government debt level to GDP means $0.5 \mathrm{pp}$ lower non-financial corporate debt. Household indebtedness in this group of countries does not seem to be strongly correlated with government debt.

Finally, the financial crisis measure shows that countries in crisis tend to have much higher levels of debt than with country and period combinations where there is no crisis. For both households and firms, the level of debt is about 10pp higher, ending up about 20pp higher for the full economy. Previously Kask et al. (2005) also found that severe financial crises are related to elevated debt levels.

The individual regression results for the level equations are presented in Table A2 in the Appendix. All the regression results in Table A2 have a constant and a trend included. The 


\section{UUSKÜLA Explaining Private Debt}

time horizon and country coverage are incomplete for many variables and they were therefore dropped from the final regression, but their economic significance should not be disregarded because of sample issues. The regression coefficients are economically very similar to random effects models that are not reported.

\subsection{Change in the debt level}

Some of the variables that are correlated with the contemporaneous debt levels may also help to forecast future developments in indebtedness. Understanding possible future developments of the debt-to-GDP ratio is crucial for macroprudential policies that seek to target possible imbalances in the economy. Of course the variables that are best for forecasting are not necessarily the same as those that have strong contemporaneous correlation, so it is interesting to examine whether the variables that are related to the level also help to improve our forecasts. In addition, the regression on future changes in the debt helps to solve some of the endogeneity problems, as future developments in debt are less likely to cause contemporaneous changes in the interest rate or GDP, partly alleviating reverse causality issues.

The regression results for the five-year ahead debt change given the current economic conditions of Equation 2 are presented in Table 2. The real interest rates are negatively related to the debt level for households. The lower interest rates are, the less the debt level grows in the future. A $1 \mathrm{pp}$ higher interest rate leads to a drop of $0.7 \mathrm{pp}$ in the debt-to-GDP ratio for households in the next five years if everything else is kept the same. Low interest rates help in paying back debt by giving lower nominal interest payments or by increasing the inflation level, which reduces the real payments. The effect through inflation is confirmed by the estimates for average inflation during the year, but though the coefficient is big in economic size, it is imprecisely estimated. Interestingly the relationship for the non-financial corporations is about one third as strong and imprecisely estimated.

As discussed above, the financial crises are related to higher levels of debt. At the same time the presence of a financial crisis predicts a decline in non-financial corporate and private debt. The magnitude of the decline is about the same as the level of the debt that was elevated during the crisis. In the five-year period after the financial crisis, the debt level for firms drops by $15 \mathrm{pp}$ and for the full economy by about $20 \mathrm{pp}$.

Higher economic confidence leads to increasing levels of debt in the future for firms and for the full economy, whereas a high level of government debt leads to deleveraging of the full economy. The size of the relationship relative to the standard deviation for household and non-financial corporate debt is small, but the effect becomes statistically significant for the total debt. A one percentage point higher government debt leads to about $0.4 \mathrm{pp}$ lower debt in the non-financial private sector, but the relationship is not estimated very precisely. Other variables, such as the GDP level, unemployment or house prices-to-income do not play a 
Table 2: Regression results for the five-year ahead change in the debt-to-GDP ratio for households, non-financial corporations and total debt.

\begin{tabular}{|l|c|c|c|}
\hline & Households & Non-fin. corp. & Total \\
\hline \hline Real interest rate & $-0.680^{* * *}$ & -0.353 & $-1.025^{*}$ \\
& $(0.216)$ & $(0.344)$ & $(0.515)$ \\
Financial crisis & -4.702 & $-15.900^{* *}$ & $-20.624^{* *}$ \\
& $(3.382)$ & $(6.629)$ & $(9.797)$ \\
Real GDP p.c. & -0.054 & -0.012 & -0.065 \\
Unemployment & $(0.190)$ & $(0.196)$ & $(0.260)$ \\
& -0.524 & 0.411 & -0.111 \\
CPI mean & $(0.491)$ & $(1.406)$ & $(1.857)$ \\
& -2.614 & -4.420 & -7.038 \\
Economic sentiment & $(5.226)$ & $(4.195)$ & $(8.514)$ \\
& 0.070 & $0.167^{*}$ & $0.238^{* *}$ \\
House prices to income & $(0.054)$ & $(0.081)$ & $(0.101)$ \\
& $-0.167^{*}$ & -0.071 & -0.237 \\
Govt. debt-to-GDP ratio & $(0.093)$ & $(0.064)$ & $(0.139)$ \\
& -0.146 & -0.204 & -0.350 \\
& $(0.152)$ & $(0.170)$ & $(0.208)$ \\
\hline Observations & 780 & 778 & 778 \\
R-squared & 0.199 & 0.150 & 0.211 \\
Number of countries & 20 & 20 & 20 \\
\hline
\end{tabular}

Notes: Robust standard errors in parentheses, ${ }^{* * *} \mathrm{p}<0.01,{ }^{* *} \mathrm{p}<0.05,{ }^{*} \mathrm{p}<0.1$.

statistically significant role in shaping debt dynamics. The relationship of the change in debt being weaker than that of the level is not entirely unexpected. Forecasting debt dynamics is complicated, as the recent financial crisis of 2007 showed, and there is no clear steady state or equilibrium level of debt that would be identical for different countries.

\section{Additional analyses}

This section shows the results of the additional regression analysis. Table 3 presents the correlation structure for the five-year averages of Equation (3). The estimated parameters provide support for the findings on the quarterly level estimation. The averaging reduces the risk of possible seasonal or spurious correlation that might arise when the model is estimated for the quarterly data.

As before, the interest rate remains negatively related to the developments of debt, and the relationship remains stronger for firms than for households. In fact the point estimate for 


\section{UUSKÜLA Explaining Private Debt}

Table 3: Debt level regression results for households, non-financial corporations and total debt at five-year moving averages.

\begin{tabular}{|l|c|c|c|}
\hline & Households & Non-fin. corp. & Total \\
\hline \hline Real interest rate & 0.613 & $-3.705^{* * *}$ & $-3.113^{* * *}$ \\
& $(0.774)$ & $(0.701)$ & $(0.851)$ \\
Financial crisis & $13.427^{*}$ & 8.570 & $21.781^{* *}$ \\
& $(6.646)$ & $(6.625)$ & $(9.673)$ \\
Real GDP p.c. & $0.429^{* * *}$ & $0.650^{* * *}$ & $1.076^{* * *}$ \\
& $(0.109)$ & $(0.174)$ & $(0.205)$ \\
Unemployment & -0.736 & $3.850^{* * *}$ & $3.139^{* * *}$ \\
& $(0.818)$ & $(1.074)$ & $(1.004)$ \\
CPI mean & $-12.126^{* * *}$ & 2.448 & -9.575 \\
& $(4.200)$ & $(10.441)$ & $(8.708)$ \\
Economic sentiment & $-0.727^{*}$ & $-1.054^{* * *}$ & $-1.787^{* * *}$ \\
& $(0.393)$ & $(0.249)$ & $(0.524)$ \\
House prices to income & $0.315^{* *}$ & -0.011 & $0.306^{* *}$ \\
& $(0.142)$ & $(0.228)$ & $(0.130)$ \\
Govt. debt-to-GDP ratio & 0.094 & $-0.854^{* * *}$ & $-0.761^{* * *}$ \\
& $(0.202)$ & $(0.292)$ & $(0.180)$ \\
\hline Observations & 762 & 760 & 760 \\
R-squared & 0.755 & 0.753 & 0.856 \\
Number of countries & 20 & 20 & 20 \\
\hline
\end{tabular}

Notes: Robust standard errors in parentheses, ${ }^{* * *} \mathrm{p}<0.01,{ }^{* *} \mathrm{p}<0.05,{ }^{*} \mathrm{p}<0.1$.

households is actually positive, but it is not different from zero at standard statistical significance levels.

Higher GDP per capita is again positively related with all three debt variables, so the relationship is not due to high frequency fluctuations. As previously, the relationship with unemployment is stronger for the non-financial corporate debt and for total debt than for household debt. Government debt is negatively related to corporate and total debt, confirming the results from the quarterly estimation. The results show that the debt level correlations are present over longer time horizons. As before, household indebtedness is related to the house price-to-income ratio, which also shows up in the total debt but is not present in the nonfinancial corporate debt.

The crisis variable could potentially have a different result for the moving average model, as the debt change results demonstrated in Table 2, where a financial crisis leads to a lower future level of debt than when there is no financial crisis. As the results of Table 3 are averages over five years, covering both contemporaneous correlation and the future and past 
values of the crisis variable, the correlation structure could change the results. This however does not happen, and the size of the positive relationship remains unchanged when the precision of the estimates is taken into account. A high level of inflation ${ }^{2}$ is negatively related to household debt but not for the non-financial corporate debt, as firms might be in a better position to insulate themselves from inflation dynamics.

Like in the moving average estimation of the level equation, the future movements in debt might also be related not only to current economic conditions, but also to a prolonged period of, say, low real interest rates, which has been discussed as one of the factors contributing to debt booms. Regression results for Equation (4), where the change in the debt variable is regressed on a moving average of the previous five years of data, are presented in Table 4. The results confirm the finding of the equation where only current economic conditions are taken into account. The volatility of the interest rate is not a big obstacle in estimating the models. Somewhat differently from Table 2, the total debt is mainly reduced because of household debt, and not non-financial corporate debt. The results show firms react faster to the interest rate than households do, so for households it tends to take longer before low interest rates translate into higher indebtedness.

Irrespective of the debt measure, higher inflation is related to a lower level of debt in the future, though the relationship is not statistically significant for the non-financial corporate debt. High economic sentiment predicts a drop in future indebtedness for firms and the total debt, which is different from the results in Table 2 where only the contemporaneous value is taken into account. A higher house price-to-income ratio shows some mean reversion effects, as, being positively correlated with the current debt, it leads to a fall in the future debt level, and unlike in the regression on current economic conditions, the relationship is now three times stronger and statistically significant.

\section{Conclusions}

After the great financial and economic crisis, several macroprudential policy measures have been put forward that may prevent financial imbalances and excessive credit growth arising, so as to make the financial sector more resistant to adverse shocks and to smooth the financial cycle. Most of these policy measures need to be taken together with other macroeconomic policies and require assessment of possible future developments in debt.

After the great financial and economic crisis, many macroprudential policy measures have been put forward that may prevent financial imbalances and excessive credit growth arising, so as to make the financial sector more resistant to adverse shocks and to smooth the financial cycle. Most of these policy measures need to be taken together with other macroeconomic policies and require assessment of possible future developments in debt. This paper studies

\footnotetext{
${ }^{2}$ The CPI mean is the same five-year average of inflation rates as in the benchmark equations.
} 


\section{UUSKÜLA Explaining Private Debt}

the relationship of household debt, non-financial corporate debt and total debt with many macroeconomic variables over many European countries and periods starting as early as 1970 for Western Europe and the 1990s for Eastern Europe.

The paper finds that a strong predictor of the debt-to-GDP ratio is real GDP per capita. The richer the country is, the higher the level of debt is. In addition, the paper finds that low interest rates are indeed related to higher debt levels. The house price-to-income ratio is also strongly and positively related to the level of debt. In contrast, the higher the government debt and inflation are, the lower the aggregate indebtedness of countries is. Moreover, the paper finds that countries that have experienced a financial crisis have on average higher debt levels than those that have not.

Table 4: Regression results for the five years ahead change in the debt-to-GDP ratio for households, non-financial corporations and the total debt, with five-year moving average economic conditions.

\begin{tabular}{|l|c|c|c|}
\hline & Households & Non-fin. corp. & Total \\
\hline \hline Real interest rate & -0.806 & $-3.782^{* *}$ & $-4.590^{*}$ \\
& $(1.054)$ & $(1.544)$ & $(2.496)$ \\
Financial crisis & 0.361 & -6.098 & -5.230 \\
Real GDP p.c. & $(8.826)$ & $(9.515)$ & $(15.112)$ \\
Unemployment & 0.065 & -0.101 & -0.042 \\
& $(0.188)$ & $(0.315)$ & $(0.495)$ \\
CPI mean & -1.118 & -1.187 & -2.410 \\
& $(1.015)$ & $(1.707)$ & $(2.301)$ \\
Economic sentiment & -15.321 & -13.915 & -29.709 \\
House prices to income & $(10.224)$ & $(11.708)$ & $(19.974)$ \\
& 0.293 & $-1.724 * * *$ & $-1.440 * *$ \\
Govt. debt-to-GDP ratio & $(0.268)$ & $(0.494)$ & $(0.577)$ \\
& $-0.330 * *$ & $-0.359 *$ & $-0.690^{* *}$ \\
& $(0.118)$ & $(0.198)$ & $(0.276)$ \\
& -0.055 & 0.117 & 0.073 \\
\hline Observations & $(0.201)$ & $(0.165)$ & $(0.284)$ \\
R-squared & 425 & 423 & 423 \\
Number of countries & 0.546 & 0.487 & 0.558 \\
\hline
\end{tabular}

Notes: Robust standard errors in parentheses, ${ }^{* * *} \mathrm{p}<0.01,{ }^{* *} \mathrm{p}<0.05,{ }^{*} \mathrm{p}<0.1$. 
Some of the variables that have strong contemporaneous correlations with debt can also forecast future developments in debt. Low interest rates lead to increasing levels of debt, whereas experiencing a financial crisis typically means that a country is going through a deleveraging process.

Last but not least, the analysis shows that several macroeconomic variables are related to current levels of debt. The relationships cannot be directly interpreted as equilibrium levels, but financial crises are on average related to levels of debt that are above what other macroeconomic fundamentals would predict. Several variables are equally useful in predicting future changes in indebtedness. Studying these relationships more closely might help policymakers predict periods where debt levels might be increasing excessively and let them introduce macroprudential measures early on.

\section{References}

Albuquerque, Bruno, Ursel Baumann and Georgi Krustev (2014), Has us household deleveraging ended? A model-based estimate of equilibrium debt. European Central Bank working paper No. 1643.

Borio, Claudio (2014), The financial cycle and macroeconomics: What have we learnt? Journal of Banking \& Finance, 45(C), 182-198.

Borio, Claudio, Marco Jacopo Lombardi and Fabrizio Zampolli (2016), Fiscal sustainability and the financial cycle. Bank for International Settlements Working Papers No. 552.

Broto, Carmen, Javier Daz-Cassou and Aitor Erce (2011), Measuring and explaining the volatility of capital flows to emerging countries. Journal of Banking \& Finance, 35(8), 1941-1953.

Campos, Julia, Neil R. Ericsson and Sir David F. Hendry (2005), Editors' Introduction to "General to Specific Modelling", Edward Elgar, 1-81.

Cecchetti, Stephen G., M. S. Mohanty and Fabrizio Zampolli (2011), The real effects of debt. Bank of International Settlements Working Paper No. 352.

Cesa-Bianchi, Ambrogio, Luis Felipe Cespedes and Alessandro Rebucci (2015), Global Liquidity, House Prices, and the Macroeconomy: Evidence from Advanced and Emerging Economies. Journal of Money, Credit and Banking, 47(S1), 301-335.

Chowdhury, A. R. (2004), Private savings in transition economies: are there terms of trade shocks? Comparative Economic Studies, 46 (4), 487-514.

Cihak, Martin, Asli Demirguc-Kunt, Erik Feyen and Ross Levine (2012), Benchmarking financial systems around the world. The World Bank Policy Research Working Paper Series No. 6175.

Detken, Carsten, Olaf Weeken, Lucia Alessi Diana Bonfim Miguel M. Boucinha, Christian Castro, Sebastian Frontczak, Gaston Giordana, Julia Giese, Nadya Jahn, Jan Kakes, Benjamin Klaus, Jan Hannes Lang, Natalia Puzanova and Peter Welz (2014), 


\section{UUSKÜLA Explaining Private Debt}

Operationalising the countercyclical capital buffer: indicator selection, threshold identification and calibration options. European Systemic Risk Board Occasional Paper No. 5.

Eggertsson, Gauti B., and Paul Krugman (2012), Debt, Deleveraging, and the Liquidity Trap: A Fisher-Minsky-Koo Approach. The Quarterly Journal of Economics, 127(3), 14691513.

Fisher, Irving (1933), The Debt-Deflation Theory of Great Depressions, Econometrica, 1(4), $337-57$

Ingves, Stefan (2014), Interview with Dagens Nyheter.

http://www.reuters.com/article/sweden-riksbank-idUSL6N0KD0UE20140103

Islam, Nazrul (1995), Growth empirics: A panel data approach. The Quarterly Journal of Economics, 110(4), 1127-1170.

Jeanne, O. (2010), Dealing with volatile capital flows. Peterson Institute for International Economics Technical Report No. 18.

Jordà, Òscar, Moritz Schularick and Alan M. Taylor (2016), The great mortgaging: housing finance, crises and business cycles ${ }_{L}$ Economic Policy, 31, (85), $107-152$.

Kask, Jana, Peeter Luikmel and Lenno Uusküla (2005), Critical Levels of Debt? Bank of Estonia Working Paper No. 3.

King, Mervyn and David Low (2014), Measuring the "world" real interest rate. National Bureau of Economic Research Working Paper No. 19887.

Kukk, Merike and Karsten Staehr (2015), Macroeconomic factors in corporate and household saving. Evidence from Central and Eastern Europe. Bank of Estonia Working Papers No. 5.

Mian, Atif and Amir Sufi (2011), House Prices, Home Equity-Based Borrowing, and the US Household Leverage Crisis. American Economic Review, 101(5), 2132-56.

Obstfeld, Maurice (2011), International liquidity: The fiscal dimension. National Bureau of Economic Research Working Paper No. 17379.

Ostry, Jonathan David, Atish R. Ghosh and Raphael A. Espinoza (2015), When Should Public Debt Be Reduced? International Monetary Fund Staff Discussion Note No. 15/10

Randveer, Martti, Lenno Uusküla and Liina Kulu (2012), The impact of private debt on economic growth. Bank of Estonia Working Paper No. 10.

Reinhart, Carmen M., Kenneth S. Rogoff and Miguel A. Savastano (2003), Debt Intolerance. Brookings Papers on Economic Activity, 34(1), 1-74.

Shaw, Edward S. (1973), Financial deepening in economic development, Oxford University Press

Svirydzenka, Katsiaryna (2016), Introducing a New Broad-based Index of Financial Development, International Monetary Fund Working Paper No. 16/5. 
Thwaites, Gregory (2015), Why are real interest rates so low? Secular stagnation and the relative price of investment goods. Bank of England Working Paper No. 564.

Tudela, Merxe and Garry Young (2005), The determinants of household debt and balance sheets in the United Kingdom. Bank of England Working Papers No. 266,

Vogel, Edgar (2014), Optimal Level of Government Debt. Matching Wealth Inequality and the Fiscal Sector. European Central Bank Working Paper Series, No 1665.

Waldron, Matt and Fabrizio Zampolli (2010), Household debt, house prices and consumption in the United Kingdom: a quantitative theoretical analysis. Bank of England Working Paper No. 379. 
UUSKÜLA Explaining Private Debt

Table A1: Data description and sources.

\begin{tabular}{|c|c|c|c|c|c|c|}
\hline Variable & & Mean & St.dev. & Min & Max & Source \\
\hline \multicolumn{7}{|c|}{ Dependent variables } \\
\hline Household debt level & & 43.78 & 27.82 & 0.60 & 146.25 & BIS, ESRB \\
\hline NFC debt level & & 74.37 & 35.47 & 6.52 & 240.11 & BIS, ESRB \\
\hline Total debt & & 118.20 & 57.05 & 7.28 & 350.33 & BIS, ESRB \\
\hline $\mathrm{HH}$ change in debt & & 9.06 & 10.18 & -14.61 & 53.07 & BIS, ESRB \\
\hline NFC change in debt & & 10.51 & 18.85 & -61.65 & 123.63 & BIS, ESRB \\
\hline Change in total debt & & 19.69 & 25.74 & -57.71 & 165.92 & BIS, ESRB \\
\hline \multicolumn{7}{|c|}{ 1. Global financial } \\
\hline Nominal Interest rate & Nominal interest rate & 7.73 & 7.89 & 0.05 & 184.37 & ESRB \\
\hline Real interest rate & Real interest rate & 2.19 & 5.76 & -53.94 & 68.71 & ESRB, ECB \\
\hline Current account balance & CA balance & -1.51 & 6.03 & -53.46 & 37.17 & ESRB \\
\hline \multicolumn{7}{|c|}{ 2. National financial } \\
\hline Leverage & Leverage ratio & 14.56 & 5.15 & 4.87 & 37.10 & ESRB \\
\hline Access to finance & Access to fin. & 103.54 & 10.86 & 74.57 & 126.45 & Eurostat \\
\hline Change in bank assets & Bank assets & 0.97 & 3.61 & -22.37 & 18.22 & ESRB \\
\hline Capital reserves to assets & Capital reserves to assets & 7.75 & 2.85 & 2.70 & 20.87 & ESRB \\
\hline Bank lending survey cred. stand. & BLSCS & 9.63 & 17.75 & -38.00 & 80.00 & $\mathrm{ECB}$ \\
\hline Loan spreads & Spread & 8.85 & 51.04 & -165.06 & 1064.3 & World Bank \\
\hline All crisis & Financial crisis & 0.10 & 0.30 & 0.00 & 1.00 & ESRB \\
\hline \multicolumn{7}{|c|}{ 3. National economy } \\
\hline GDP per capita & 100*Real GDP p.c. & 446.36 & 26.58 & 335.34 & 493.81 & Eurostat, ESRB \\
\hline GDP per capita growth & $100 *$ Real GDP growth & 0.54 & 1.33 & -12.94 & 12.69 & Eurostat, ESRB \\
\hline Negative growth rates & Recession & -0.14 & 0.62 & -14.49 & 0.00 & Eurostat, ESRB \\
\hline Unemployment & Unemployment & 7.75 & 4.09 & 0.50 & 26.15 & Eurostat \\
\hline Change in CPI & Inflation & 1.79 & 4.10 & -4.83 & 78.85 & $\mathrm{ECB}$ \\
\hline $\mathrm{CPI}$ volatility & CPI vol. & 1.07 & 2.28 & 0.01 & 41.03 & Eurostat, ESRB \\
\hline Average inflation & $\mathrm{CPI}$ mean & 1.56 & 1.69 & -0.05 & 23.13 & Eurostat, ESRB \\
\hline Economic sentiment index & Economic sentiment & 100.38 & 9.87 & 62.10 & 126.60 & Eurostat \\
\hline \multicolumn{7}{|c|}{ 4. Households and real estate } \\
\hline House owners, all & HOall & 76.3 & 9.94 & 52.40 & 97.50 & Eurostat \\
\hline House owners with mortgage & HOwm & 24.81 & 17.44 & 0.50 & 68.00 & Eurostat \\
\hline House owners without mortg. & HOnm & 51.59 & 24.96 & 2.80 & 96.90 & Eurostat \\
\hline House price to income & House prices to income & 100.00 & 20.67 & 43.88 & 166.01 & ESRB \\
\hline Real equity price & Equity prices & 4.14 & 1.00 & 1.86 & 8.76 & ESRB \\
\hline Real estate price & RE price & 73.78 & 30.56 & 14.21 & 218.11 & ESRB \\
\hline Commercial real estate price & Comm. RE price & 4.70 & 0.26 & 3.90 & 5.39 & ESRB \\
\hline
\end{tabular}


Review of Economic Analysis 8 (2016) 153-176

Table A1 continued....

\begin{tabular}{|c|c|c|c|c|c|c|}
\hline Variable & & Mean & St.dev. & Min & Max & Source \\
\hline \multicolumn{7}{|c|}{ 5. Demographics } \\
\hline Dependency ratio & Dependency rat. & 51.90 & 5.56 & 38.60 & 73.7 & Eurostat \\
\hline Household size & HHsize & 2.48 & 0.27 & 1.90 & 3.10 & Eurostat \\
\hline \multicolumn{7}{|c|}{ 6. Government } \\
\hline Government debt to GDP & Govt. debt-to-GDP ratio & 55.34 & 30.83 & 1.91 & 170.3 & ESRB \\
\hline Government budget balance & Govt. budget balance & -2.68 & 3.79 & -41.00 & 9.9 & Eurostat \\
\hline \multicolumn{7}{|c|}{ 7. Institutions } \\
\hline Stock market capitalisation & SMC & 38.41 & 36.71 & 0.06 & 271.74 & World Bank \\
\hline Time to start a business & TSB & 19.61 & 18.13 & 2.50 & 138.00 & World Bank \\
\hline
\end{tabular}


UUSKÜLA Explaining Private Debt

Table A2: Additional regression results for bivariate models of the quarterly level regression on household, non-financial corporate and total debt.

\begin{tabular}{|c|c|c|c|c|c|}
\hline & Households & Non-fin. corp. & Total & Obs. & R-squared \\
\hline \multicolumn{6}{|c|}{ 1. Global financial } \\
\hline Real interest rate & $\begin{array}{l}-0.377^{*} \\
(0.198)\end{array}$ & $\begin{array}{l}-0.677 \\
(0.404)\end{array}$ & $\begin{array}{c}-1.084^{*} \\
(0.528)\end{array}$ & 2,327 & 0.579 \\
\hline Nominal interest rate & $\begin{array}{l}-0.344 \\
(0.303)\end{array}$ & $\begin{array}{l}-0.104 \\
(0.429)\end{array}$ & $\begin{array}{l}-0.459 \\
(0.586)\end{array}$ & 2,327 & 0.568 \\
\hline CA balance & $\begin{array}{l}-0.322 \\
(0.203)\end{array}$ & $\begin{array}{c}-0.139 \\
(0.246)\end{array}$ & $\begin{array}{l}-0.463 \\
(0.381)\end{array}$ & 2,112 & 0.523 \\
\hline \multicolumn{6}{|c|}{ 2. National financial } \\
\hline Leverage ratio & $\begin{array}{c}1.193 * * * \\
(0.331)\end{array}$ & $\begin{array}{c}-0.611 \\
(1.045)\end{array}$ & $\begin{array}{c}0.580 \\
(1.239)\end{array}$ & 1,078 & 0.599 \\
\hline Access to fin. & $\begin{array}{c}-0.249 * * \\
(0.116)\end{array}$ & $\begin{array}{l}-0.355 \\
(0.244)\end{array}$ & $\begin{array}{l}-0.604^{*} \\
(0.342)\end{array}$ & 612 & 0.321 \\
\hline Bank assets & $\begin{array}{c}0.044 \\
(0.083)\end{array}$ & $\begin{array}{l}-0.280 \\
(0.314)\end{array}$ & $\begin{array}{l}-0.240 \\
(0.376)\end{array}$ & 1,110 & 0.598 \\
\hline CapitalRes2totassets & $\begin{array}{c}-1.268 * * \\
(0.528)\end{array}$ & $\begin{array}{c}-0.354 \\
(1.227)\end{array}$ & $\begin{array}{l}-1.620 \\
(1.384)\end{array}$ & 1,134 & 0.609 \\
\hline Spread & $\begin{array}{c}-1.153^{* *} \\
(0.551)\end{array}$ & $\begin{array}{l}-1.201 \\
(1.034)\end{array}$ & $\begin{array}{c}-2.349 * * \\
(0.980)\end{array}$ & 1,680 & 0.538 \\
\hline BLSCS & $\begin{array}{c}0.075 \\
(0.049)\end{array}$ & $\begin{array}{c}0.150 * * * \\
(0.041)\end{array}$ & $\begin{array}{c}0.224^{* *} \\
(0.079)\end{array}$ & 356 & 0.507 \\
\hline Financial crisis & $\begin{array}{c}8.971 * * * \\
(1.745)\end{array}$ & $\begin{array}{c}17.908 * * * \\
(4.085)\end{array}$ & $\begin{array}{c}27.154^{* * *} \\
(4.851)\end{array}$ & 2,425 & 0.646 \\
\hline \multicolumn{6}{|c|}{ 3. National economy } \\
\hline Recession & $\begin{array}{c}-1.731 * * * \\
(0.333)\end{array}$ & $\begin{array}{c}-2.881 * * * \\
(0.662)\end{array}$ & $\begin{array}{c}-4.634 * * * \\
(0.922)\end{array}$ & 2,425 & 0.589 \\
\hline Real GDP growth & $\begin{array}{c}-1.372^{* * *} \\
(0.260)\end{array}$ & $\begin{array}{c}-2.185^{* * *} \\
(0.512)\end{array}$ & $\begin{array}{c}-3.568 * * * \\
(0.740)\end{array}$ & 1,850 & 0.683 \\
\hline Real GDP p.c. & $\begin{array}{l}-0.009 \\
(0.140)\end{array}$ & $\begin{array}{l}-0.275 \\
(0.226)\end{array}$ & $\begin{array}{l}-0.282 \\
(0.336)\end{array}$ & 1,861 & 0.671 \\
\hline Unemployment & $\begin{array}{l}-0.651 * \\
(0.335)\end{array}$ & $\begin{array}{c}0.500 \\
(0.769)\end{array}$ & $\begin{array}{l}-0.155 \\
(0.987)\end{array}$ & 2,407 & 0.578 \\
\hline Inflation & $\begin{array}{c}0.461 \\
(1.017)\end{array}$ & $\begin{array}{c}2.188 \\
(1.644)\end{array}$ & $\begin{array}{c}2.692 \\
(1.813)\end{array}$ & 2,425 & 0.585 \\
\hline CPI vol & $\begin{array}{l}-0.507 \\
(0.464)\end{array}$ & $\begin{array}{c}1.235 \\
(1.210)\end{array}$ & $\begin{array}{c}0.729 \\
(1.281)\end{array}$ & 2,313 & 0.611 \\
\hline CPI mean & $\begin{array}{l}-0.294 \\
(0.766)\end{array}$ & $\begin{array}{c}1.267 \\
(1.319)\end{array}$ & $\begin{array}{c}0.968 \\
(1.511)\end{array}$ & 2,331 & 0.612 \\
\hline Economic sentiment & $\begin{array}{c}-0.192^{* * *} \\
(0.044)\end{array}$ & $\begin{array}{c}-0.281 * * * \\
(0.078)\end{array}$ & $\begin{array}{c}-0.473 * * * \\
(0.105)\end{array}$ & 1,922 & 0.696 \\
\hline
\end{tabular}


Review of Economic Analysis 8 (2016) 153-176

Table A2 continued: ...

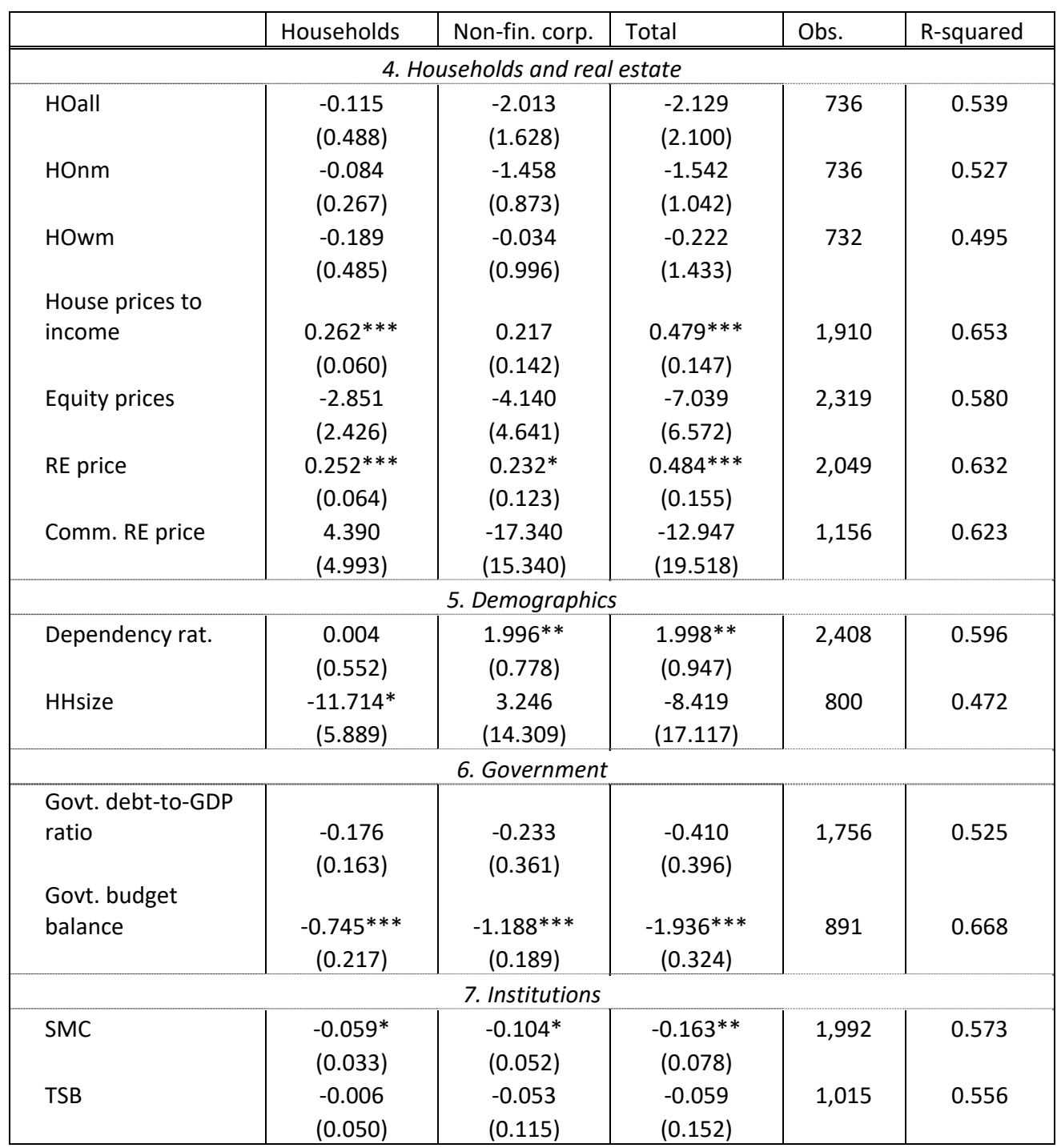

Notes: Robust standard errors in parentheses, $* * * \mathrm{p}<0.01,{ }^{* *} \mathrm{p}<0.05, * \mathrm{p}<0.1$. Regression results of household, non-financial corporate and total debt at quarterly frequency at the respective variable. Linear trends included in all models. Number of observations (Obs.) and R-squared shown for the model on total debt-to-GDP ratio. See Table A1 for explanations of variable notation. 